\title{
Analysis of Evolution Dynamics of Chinese Credit Reporting System in the Internet Environment
}

\author{
Yuanxiang Dong \\ Shanxi University of Finance and Economics \\ Taiyuan, Shanxi. \\ dyx_paper@163.com. \\ Guiming Liu \\ Shanxi University of Finance and Economics \\ Taiyuan, Shanxi. \\ 2358416818@qq.com
}

\author{
Chenjing Hou \\ Shanxi University of Finance and Economics \\ Taiyuan, Shanxi. \\ 18435155872@163.com \\ Weimei $\mathrm{Hu}$ \\ Shanxi University of Finance and Economics \\ Taiyuan, Shanxi. \\ 625762394@qq.com
}

\begin{abstract}
This paper studied the effectiveness of the Internet for credit reporting system and the applicability of the two credit reporting models, market-oriented model and government-oriented model, in China. Firstly, on the basis of system dynamics modeling, structural models of two credit reporting systems were constructed: with the presence of the Internet and with the absence of the Internet, and the corresponding evolution processes of Chinese social credit system were simulated. By comparing the two models, the validity of the Internet to credit reporting system is verified. Secondly, by using system simulation, this paper studied the influence of two credit reporting models on operating efficiency of credit reporting system. The results show that the Internet helps to promote the development of credit reporting market. And in the internet environment, the credit reporting system of market-oriented is more efficient.
\end{abstract}

Keywords-Credit reporting system; the Internet environment; system dynamics; market-oriented; government-oriented

\section{INTRODUCTION}

Credit reporting is the foundation and an important link of the establishment of social credit system, which is helpful to prevent financial risks and improve the efficiency of financial markets [1]. Internet credit reporting emerges with the development of the Internet and big data technology. It can reduce the cost of information collection and transmission and the application areas have also been beyond the scope of traditional financial credit. For example, it can credit data online such as consumer behaviors, social relations and payment habits, making it possible to establish a credit system covering every social subject.

The Internet environment has brought challenges and opportunities to traditional credit reporting model. Therefore, the effect of the Internet on current Chinese credit reporting system and taking which model of credit reporting in the internet environment can improve operating efficiency of the entire system have become an issue that urgently needs to be

This research is supported by the National Natural Science Foundation of China (Grant No. 71701116), Ministry of Education in China Project of Humanities and Social Sciences (Grant No. 15YJC630016) and the Subject of Philosophy and Social Sciences in Shanxi "Research on the construction of credit system in Shanxi Province under the background of Internet finance: credit collection model and assessment support" studied in the construction of credit system in China.

\section{LITERATURE REVIEWS}

The existing researches on Chinese credit reporting system in the internet environment focus more on two aspects: the selection of credit reporting models and the path of credit system construction. Wang analyzed the important role of credit reporting system in the Internet era and proposed suggestions on the construction of credit reporting system [2]. Wang and Wang analyzed the significance of Internet credit reporting and proposed suggestions on the construction of Internet credit reporting system based on the current status of Internet credit reporting in China [3]. Sun and Gao conducted a comparative analysis on the relevant elements of the three core links of Internet personal credit reporting in China and other countries. They thought the Internet personal credit reporting is not exactly the same as the big data credit reporting [4].

Previous researches have confirmed the effect of Internet credit reporting on credit system, but they are mostly based on theoretical analysis and not verified with the help of system analysis tools and simulation. This paper analyzes the interactive feedback relationship among different subjects in the credit reporting system and constructs system dynamics model of credit reporting system by using system dynamics. The Venism software is used to simulate for verifying the validity of the Internet to credit reporting system and studying in China the selection of the two credit reporting models which have been widely applied, market-oriented represented by the United States and government-oriented represented by Europe [5].

\section{MODEL CONSTRUCTION}

\section{A. Model index analysis}

\section{1) Internet credit reporting}

Internet credit reporting is a credit which relies on the Internet platform, such as Alibaba's ANT, Tencent Credit Bureau of Tencent, online P2P lending platform and so on. Internet credit reporting has been affected by the 
development level of the Internet finance, and the higher development level indicates the stronger ability of Internet credit reporting.

\section{2) Basic credit reporting}

Basic credit reporting is carried out by the People's Bank of China, and they provide basic credit products. The basic credit reporting is mainly influenced by the government-oriented ability and Internet credit reporting. On the one hand, the stronger the government-oriented ability is, the more complete the basic credit reporting database is; on the other hand, Internet credit reporting can help to expand data sources and coverage of basic credit reporting.

\section{3) Social credit reporting}

Social credit reporting is conducted by social institutions, and they provide personalized credit reporting products. Social credit reporting is subject to the dual influence of market-oriented ability and Internet credit reporting. On the one hand, the stronger market-oriented ability can stimulate social institutions' initiative, and then they would produce more credit products; on the other hand, Internet credit reporting can expand data sources and coverage of social credit reporting. In addition, the market-oriented ability is influenced by government-oriented ability, and the stronger market-oriented ability indicates the weaker government-oriented ability.

\section{4) Social credit system}

The social credit system is mainly composed of basic credit reporting and social credit reporting, and is influenced by information sharing ability of basic credit reporting and social credit reporting. The basic credit reporting and social credit reporting have a positive causal relationship with social credit system. The stronger the credit information sharing ability is, the more complete the social credit system is.

\section{5) Credit reporting products}

Credit reporting products are products formed by credit agencies through the operation of analyzing credit reporting data, which can be adopted by financial institutions and as the basis of decision-making. In this paper, the quantity of credit reporting products is considered as indicators to measure the operating efficiency of credit reporting system and is used to judge the impact of the Internet and the two credit reporting models, market-oriented and government-oriented, on credit reporting system. Credit products are converted from credit reporting data, so credit reporting data has a positive impact on credit reporting products. And the credit reporting data is affected by social credit system and economic environment.

\section{B. Model construction}

Through the analysis of main indicators, we can find out the causality between the indicators, and then build flow charts of traditional credit reporting model and the credit model in the internet environment, as is shown in Fig. 1, 2. Based on data collection and analysis, structural equations between variables can be established:

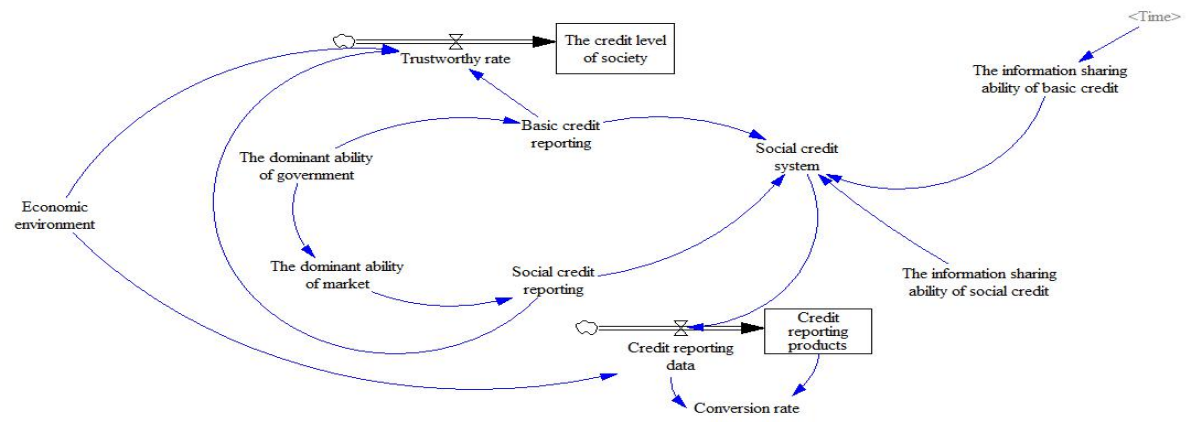

Fig. 1. The flow chart of traditional credit reporting model.

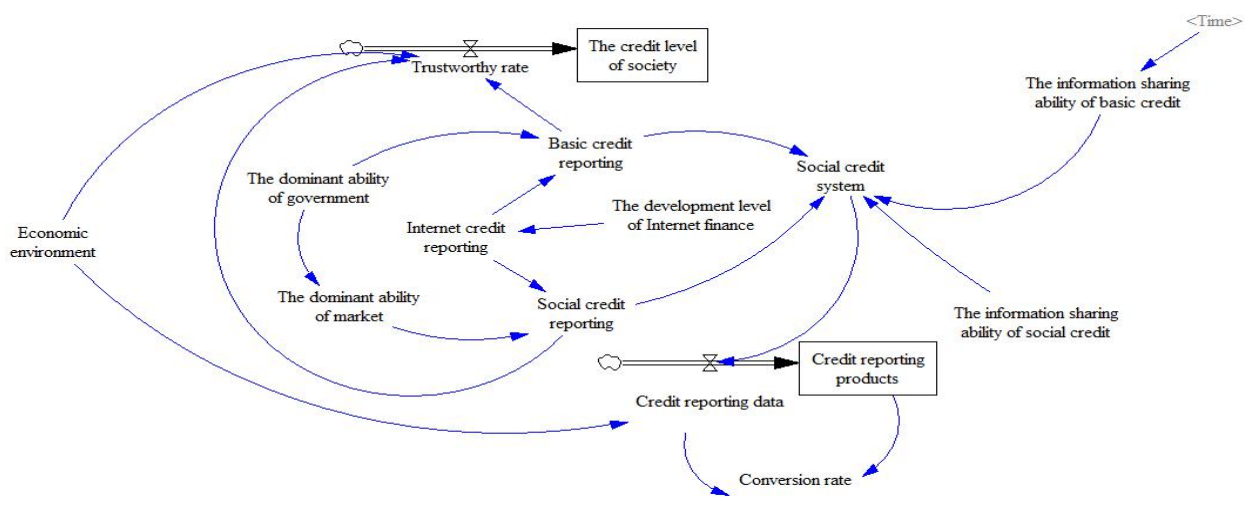

Fig. 2. The flow chart of credit reporting model in the internet environment. 
Social credit system $=$ basic credit reporting*(1+ information sharing ability of basic credit) + social credit reporting*(1+ information sharing ability of social credit) (1)

Credit reporting products $=$ credit reporting data Initial value $=10$

The dominant ability of government $=0.2$

The dominant ability of market $=1$ - the dominant ability of government

Basic credit reporting $=\operatorname{RAMP}(0.1,0,100)^{*}\left(179^{*}\right.$ dominant ability of government) + (Internet credit reporting*0.5) Description: RAMP is a ramp function with a slope of 0.1 , increasing from 0 to 100 . Assuming that the total credit level is "179", and basic credit reporting accounted for the proportion of Internet credit reporting is 0.5 .

Social credit reporting $=\operatorname{RAMP}(0.3,0,100) *(179 *$ dominant ability of market) + (Internet credit reporting*0.5) Description: RAMP is a ramp function with a slope of 0.3 , increasing from 0 to 100 . Assuming that the total credit level is "179", and social credit reporting accounted for the proportion of Internet credit reporting is 0.5.

Internet credit reporting $=$ development level of Internet finance $* 100$

The development level of Internet finance $=$ RAMP $(0.2,0$, 100) Description: Using a ramp function with a slope of 0.2 increasing from 0 to 100 .

Trustworthy rate $=$ (basic credit reporting $* 0.6+$ social credit reporting $* 0.4)+$ economic environment

Social credit level $=$ Trustworthy rate $\quad$ Initial value $=10$

Credit reporting data $=$ social credit system $*(1+$ economic environment)

Conversion rate $=$ credit reporting data $/$ credit reporting products

Economic environment $=$ RANDOM NORMAL $(-0.06$, 0.06, 0, 0, 777) Description: economic environment randomly takes 777 values between -0.06 and 0.06

Information sharing ability of basic credit $=$ WITHLOOKUP(time)

Lookup:[(0,0)-(100,10)],(10,0.1),(20,0.2),(30,0.3),(40,0.4),(50, $0.5),(60,0.6),(70,0.7),(80,0.8),(90,0.9),(100,1)$ Description: the table function of basic credit information sharing ability

Sharing ability of social credit $=0.2$

\section{Simulation AND ANALysis OF Model}

Based on the model constructed in the previous section, the quantity of credit reporting products are obtained through changing the parameters of influencing factors. The simulation results are as follows.

\section{A. The impact of Internet credit reporting on the quantity of credit reporting products in different dominant models}

This paper verifies the influence of the Internet on credit reporting system under different dominant models based on the changes of credit reporting products' quantity. Fig. 3 shows the impact of Internet credit reporting on credit reporting products under the market-oriented model (the value of market-oriented ability is 0.8 ). The curve 1,2 respectively represents the number movements of credit reporting products with the presence of Internet credit reporting and with the absence of Internet credit reporting. By comparing the two curves, it can be seen that the presence of Internet credit reporting can generate more credit reporting products under the market-oriented model. Fig. 4 shows the impact of Internet credit reporting on credit reporting products under the government-oriented model (the value of government-oriented ability is 0.8 ). And the curve1, 2 respectively represent the quantity of credit reporting products with the presence of Internet credit reporting and with the absence of Internet credit reporting. By comparing the two curves, it can be seen that the presence of Internet credit reporting can generate more credit reporting products under government-oriented model.

By analyzing Fig. 3, 4, it can be concluded that, with other parameters being constant, whether it is government-oriented or market-oriented, the Internet credit reporting has a positive effect on entire credit system and makes credit reporting products more abundant.

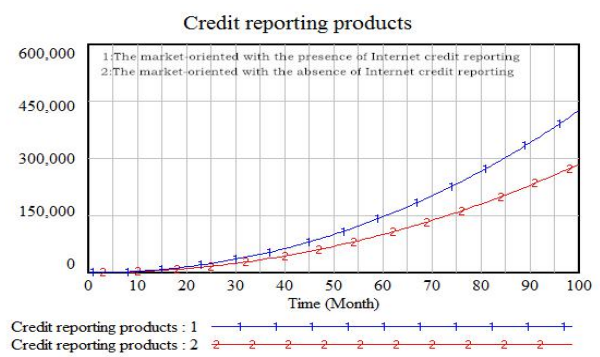

Fig. 3. The impact of Internet credit reporting on the quantity of credit reporting products under market-oriented model.

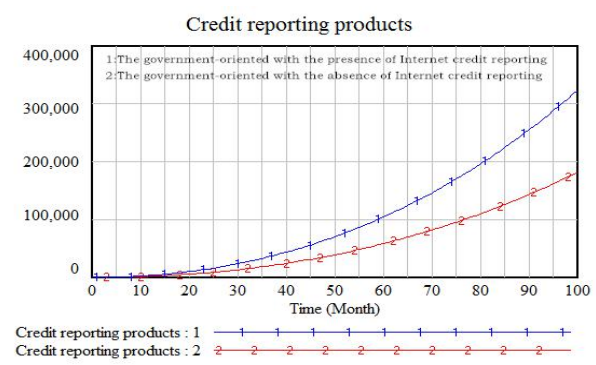

Fig. 4. The impact of Internet credit reporting on the quantity of credit reporting products under government-oriented model.

\section{B. This paper verifies the influence of different dominant models on credit reporting system based on the changes of credit reporting products' quantity}

In Fig. 5, curve 1, 2 respectively represent the quantity of credit reporting products under market-oriented model and government-oriented model. And the values of the two dominant abilities are respectively $0.8,0.8$.The simulation results show that with other parameters unchanged, the number of credit reporting products under market-oriented model is more than under government-oriented model. 


\section{The influence of different social credit levels on the quantity of credit reporting products}

For studying the impact of different social credit levels on credit reporting system, with other parameters unchanged, the values of social credit levels should be gradually increased so as to observe the changes of credit reporting products' quantity. In Fig. 6, the curve 1, 2 respectively shows the number movements of credit reporting products under the higher credit level of society and the lower. And the values of social credit levels are $0.8,0.2$. From the simulation results, it can be seen that when the credit level of entire society is raised, the quantity of credit reporting products will be increased accordingly.

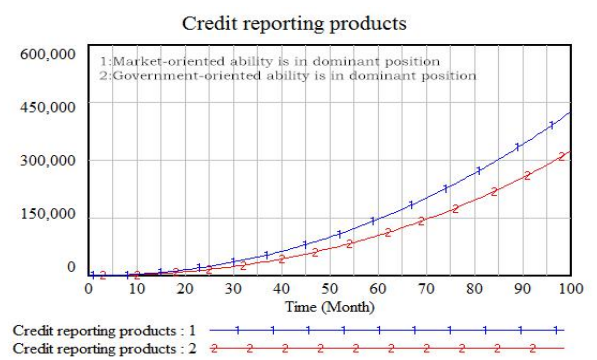

Fig. 5. The influence of different dominant models on the quantity of credit reporting products.

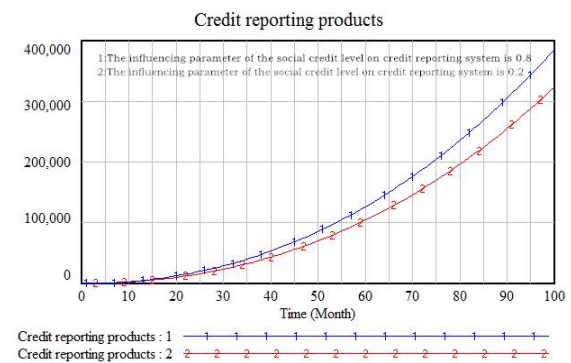

Fig. 6. The influence of social credit levels on the quantity of credit reporting products.

\section{The influence of Internet credit reporting on the quantity of} credit reporting products based on different proportions of basic credit reporting and social credit reporting

In order to study the influence of Internet credit reporting on the quantity of credit reporting products based on different proportions of basic credit reporting and social credit reporting, this paper verifies this impact based on the changes of the credit reporting products' quantity. In Fig. 7, three different proportions were selected for comparative analysis. Curve 1, curve 2 and curve 3 respectively represent the number movements of credit reporting products when Internet credit reporting accounts for the proportions of basic credit reporting and social credit reporting are $0.5,0.8 ; 0.5,0.5 ; 0.2,0.2$. Comparing curve 1 with curve 2 , it can be seen that with other parameters unchanged, when Internet credit reporting accounts for the proportion of basic credit reporting is 0.5 , the greater proportion the Internet credit reporting accounts for social credit reporting is, the more the quantity of credit reporting products is. Comparing curve 2 with curve 3 , it can be seen that with other parameters unchanged, when Internet credit reporting accounts for the same proportion of basic credit reporting and social credit reporting, the greater proportion the Internet credit reporting accounts for results in the more quantity of credit reporting products. In summary, the greater the proportion the Internet credit reporting accounts for basic credit reporting and social credit reporting, the more quantity the credit reporting products is; and by increasing the proportion the Internet credit reporting accounts for social credit reporting, the quantity of credit reporting products can be further increased.

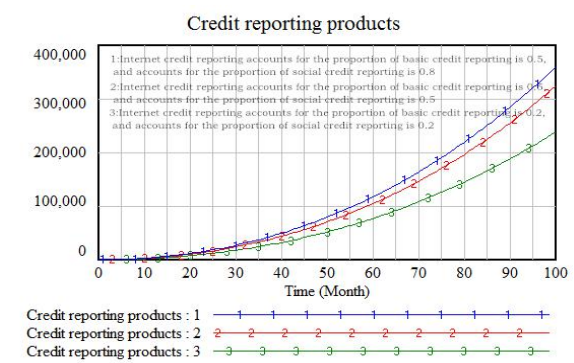

Fig. 7. The influence of Internet credit reporting on the quantity of credit reporting products based on different proportions of basic credit reporting and social credit reporting.

\section{CONCLUSIONS}

This paper studies the relationship between the Chinese credit reporting system indexes, which are Internet credit reporting, basic credit reporting, social credit reporting, social credit system and credit reporting products, and then finds out the causal chain of credit reporting system. Based on this, the causality graph and flow chart of Chinese credit reporting system in the internet environment are constructed. It can be concluded from the above simulation: (1) The Internet helps to improve the efficiency of credit reporting system. (2) In the internet environment, credit reporting system of market-oriented is more efficient than government-oriented. (3) The credit information sharing degree has a positive impact on Internet credit reporting. And the greater proportion of Internet credit reporting accounts for the entire social credit reporting is, the more efficient the credit reporting system is. (4) The higher social credit level helps to improve the efficiency of credit reporting system.

\section{REFERENCES}

[1] D.K. Li, C. Liu, J.R. Pang, Study on the effect of financial infrastructure in promoting economic development-take China credit reporting system as an example, Journal of Financial Research, 2016(2), pp.180-188.(In Chinese).

[2] Z.R. Wang, Credit reporting system in the Internet era, China finance, 2016(5), pp.92-93.(In Chinese).

[3] S.T. Wang, Y. Wang, The development status of Internet credit reporting in China and the construction of credit reporting system, Review of economic research, 2016(10), pp. 89-92. (In Chinese).

[4] J.G. Sun, Y. Gao, A comparative study on the development factors of modern personal credit reporting industry, Financial theory and practice, 2017(8), pp.53-58.(In Chinese).

[5] Z.Q. Xie, X.F. Liu, China credit reporting system: model construction and route choice, Shanghai finance, 2014(7), pp.63-66.(In Chinese). 